\title{
Commerce and Conservation on the Upper Mississippi River
}

\author{
JOHN O. ANFINSON
}

FRAMED BY TOWERING BLUFFS, the Mississippi River at Guttenberg, Iowa, features a unique and historic landscape, a landscape imposed on the area less than seventy years ago by supporters of two strong and often conflicting movements. The adherents of one movement dreamed of making the river a commercial highway. Backers of the other hoped to preserve and develop it for fish and wildlife and for its scenic beauty. The natural river met neither group's needs, and both worked to change it. The development of the upper Mississippi River thus represents a compromise-albeit an uneven one-between the proponents of these two movements and speaks to their differing visions for the river. ${ }^{1}$

During the past 125 years, midwesterners have argued that they needed access to the ocean and the world through the Mississippi to achieve their manifest destiny. To become a commercial and industrial power as strong as the East, as well as the nation's breadbasket, the natural river would require great changes. In response to the strong regional demand for cheap and reliable transportation, Congress authorized three major navigation projects for the upper Mississippi River: the $4 \frac{1}{2}-,, 6-$, and 9 -foot channel projects. Under the latter project, Congress directed the U.S. Army Corps of Engineers to construct twenty-three locks and dams between Red Wing, Minnesota, and Alton, Illinois, and add new locks at Locks and

1. Generally, the upper Mississippi River is the river between Minneapolis and St. Louis. Sissel Johannessen, an archeologist in my office, provided invaluable research for this study. 
Dams 1 and 19, which had been constructed under earlier projects. $^{2}$

During those same 125 years, the conservation movement on the upper Mississippi River grew with larger national and regional conservation efforts. Scholars have identified many factions within the early conservation movement, but they acknowledge that two groups dominated it. One hoped to preserve untainted large parts of the nation's wild and scenic areas, including the flora and fauna that inhabited them. The other group sought to develop those areas through scientific management. The closing of the frontier and the devastating effect of America's expanding industry and population on the country's natural resources motivated both groups. With adherents to both camps, Iowa led the movement to conserve the upper Mississippi River's resources, especially its fisheries. ${ }^{3}$

The nine-foot channel project, by threatening to reshape the upper Mississippi River, led many conservationists to oppose or at least question it. Their efforts to influence the project marked a watershed in the relationship between conservation and navigation interests. From the mid-nineteenth century through the early twentieth century, those two interests had grown along separate paths. Before 1925, navigation had been supreme, conservationists simply reacting to navigation projects. With the nine-foot channel project, conservationists successfully forced the Corps of Engineers and navi-

2. The Corps of Engineers measured channel depths against the low-water year of 1864 . With the $4 \frac{1}{2} 2$-foot channel, the Corps hoped to maintain a channel depth of at least $4 \frac{1}{2}$ feet if the river got as low as it did in 1864 .

3. Samuel P. Hays, Conservation and the Gospel of Efficiency: The Progressive Conservation Movement, 1890-1920 (New York, 1974); and Rebecca Conard, "The Conservation Movement in Iowa, 1857-1942," National Register of Historic Places Multiple Property Documentation Form, State Historical Society of Iowa (1991), E-2-6, whose excellent work on this nomination led to this study. See also W. J. McGee, "The Conservation of Natural Resources," Proceedings of the Mississippi Valley Historical Association for the Year 1909-1910 3 (Cedar Rapids, 1911), 361-79; Gifford Pinchot, The Fight for Conservation (1910; reprint, Seattle, WA, 1967); Carolyn Merchant, ed., Major Problems in Environmental History (Lexington, MA, 1993), chaps. 9-11. 
gation boosters to begin taking into account the effect of navigation improvements on the river's fish and wildlife.

At Guttenberg the two interests compromised to form the area's unique landscape. That landscape comprises two sites. One is Lock and Dam No. 10, which Congress authorized as part of the nine-foot channel project in 1930 to satisfy navigation boosters. The other is the Guttenberg National Fish Hatchery, which conservationists won in 1938 to compensate for the project's effect on the river's fisheries. Both sites represent a culmination of important forces that have shaped the upper Mississippi River.

IN ITS NATURAL CONDITION the upper Mississippi River was characterized by uncounted side channels, backwaters, snags, sandbars, and wide shallows-delaying, stranding, and sometimes sinking steamboats. Spring floods often rerouted the navigation channel. At low water, usually during the late summer or early fall, no continuous channel existed. Rather, the river flowed along one side for a short reach and then crossed to the other. The natural river undermined its banks, swallowing the rocks, soil, and trees that fell into it, giving birth to new hazards.

Before 1866, Congress authorized no comprehensive program to eliminate natural obstacles to river transportation. Not enough people lived in the region to justify or push for such a program. Demand had begun growing during the $1850 \mathrm{~s}$, as the steamboat trade entered its golden age, but before Congress could act, the economic panic of 1857 and the Civil War intervened. In 1866 Congress authorized the Corps of Engineers to begin dredging, snagging, clearing overhanging trees, and removing sunken vessels. But the Corps made few changes, and the river remained unnavigable for much of the year.

As the Midwest's population and agricultural production grew following the Civil War and as railroads began monopolizing bulk shipping in the Midwest, pressure mounted on Congress to authorize more significant improvements. Responding to this demand, the Senate created a commission to study internal transportation. Headed by Minnesota Senator William Windom, the commission concluded that water- 
way improvement offered the best solution to the region's transportation needs. Based on the commission's recommendations and continued popular demand, Congress on June 18,1878 , authorized the $4 \frac{1}{1} 2$-foot channel project, which would create a continuous navigation channel, $4 \frac{1}{2} 2$-feet deep at low water, between St. Paul and St. Louis. That project would fundamentally change the upper Mississippi's physical and ecological character. Returning to the Mississippi in 1882, Mark Twain dryly observed, "The military engineers ... have taken upon their shoulders the job of making the Mississippi over again - $a$ job transcended in size by only the original job of creating it." 4

To achieve the $4 \frac{1}{2}$-foot channel, the Corps built wing dams and closing dams, protected shorelines, and dredged stubborn bars. Wing dams-long, narrow piers of rock and brush-stabbed into the river from the main shoreline or from the bank of an island. The Corps placed the dams in a series along one or both sides of the channel to reduce its width. Closing dams, which ran from the shore to an island or from one island to another, diverted more water to the main channel. Narrowing the river, wing dams increased its velocity, enabling it to cut through sand and debris. Moving faster, the river carried more sediment, some of which it deposited in the calmer waters behind or between the wing dams. Over the years, sand and vegetation filled the space between the dams. In this way, the Corps constricted the river, gradually moving its banks inward, changing its landscape and its ecology. ${ }^{5}$

4. Senate, Report of the Select Committee on Transportation Routes to the Seaboard, 43d Cong., 1st sess., 1874, S. Rep. 307, pt. 1, 7-8, 188, 198-99, 211, 213, 243; Mark Twain, Life on the Mississippi (1896; reprint, New York, 1990), 138. Although Twain was referring to the lower river, the description fits the upper river just as well.

5. The Corps began working on the Des Moines and Rock Island Rapids before the Civil War, surveying them and removing rock. Because rock formed the channel bottom through these rapids, the Corps did not use channel constriction there. Roald Tweet, "A History of Navigation Improvements on the Rock Island Rapids: The Background of Locks and Dam 15," U.S. Army, Corps of Engineers, Rock Island District (Rock Island, IL, 1980), 1-15. 


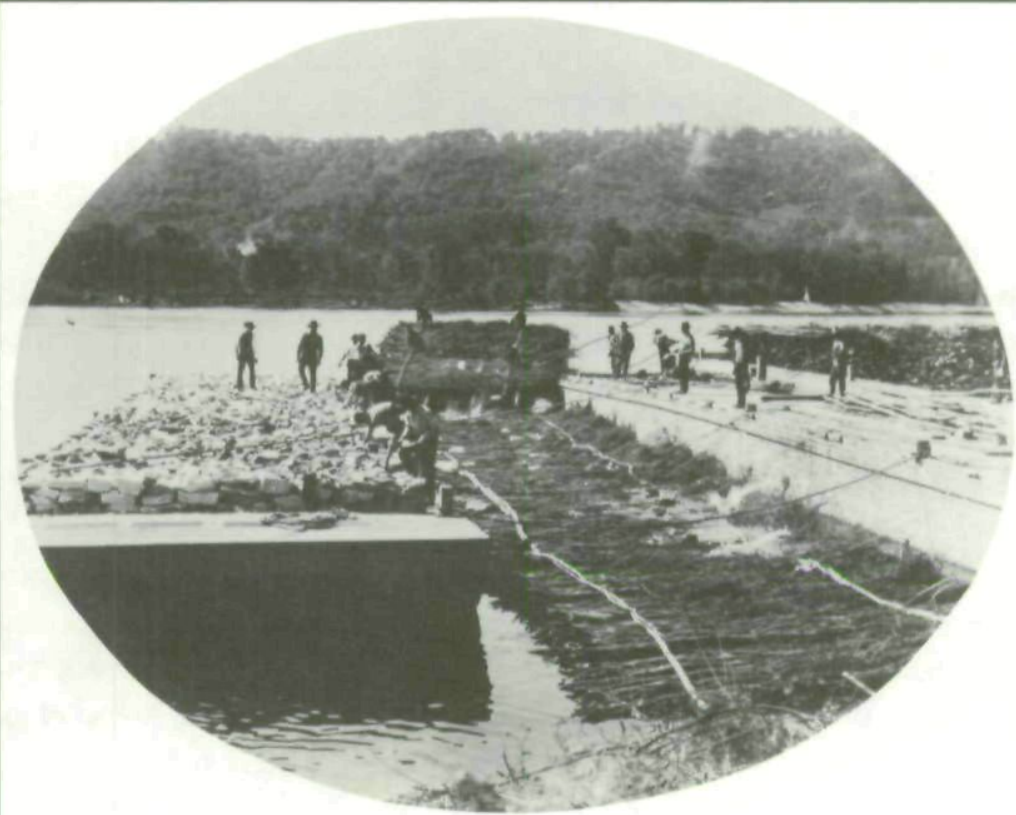

Workers heave rocks onto a willow mattress to make a wing dam, while men on the opposite barge ensure that the mattress sinks evenly. Other men assemble and lower the next mattress into place. The workers would add enough layers of rock and brush to make the wing dam protrude several feet above the water's surface. Photo by Henry P. Bosse, courtesy St. Paul District, U.S. Army Corps of Engineers.

Despite the Corps' efforts, river traffic declined. By 1880, the heyday of steamboating had passed. Railroads had taken most of the grain and passenger traffic away, and by 1890 timber rafting remained the only significant commerce. ${ }^{6}$ Timber products dominated the upper river's commerce from the

6. Grain traffic through the Des Moines Rapids Canal and at St. Louis during the late nineteenth century illustrates the decline of the freight trade on the upper river. In 1879 and 1880 more than two million bushels of grain passed through the canal, but it registered only 400,000 bushels at the end of the decade and fewer than 56,000 bushels after 1895. See Frank H. Dixon, A Traffic History of the Mississippi River System (Washington, DC, 1909), 51. Timothy R. Mahoney, "Down in Davenport: A Regional Perspective on Antebellum Town Economic Development," Annals of Iowa 50 (1990), 451-74, provides a good summary of the effects of railroad expansion on the steamboat trade, on a river town, and on the Midwest's shipping patterns. 
1870 s to the first decade of the twentieth century. Timber shipping, however, fell with the white pine forests of western Wisconsin and northern Minnesota. At its peak, during the years 1893 and 1894, one hundred sawmills operated on the river between Minneapolis and St. Louis. Eighty sawmills remained in 1900, thirty-six in 1903, and just one in 1913. Raftboats followed a similar decline. Of more than one hundred raftboats plying the upper river in 1893, twenty remained in 1906, and only four in 1912. In 1915 the last raftboat paddled from Hudson, Wisconsin, to Fort Madison, Iowa. $^{7}$

Timber's demise revealed a problem that had been developing for nearly fifty years. The Mississippi had become a one-commodity river. As that commodity disappeared, the river's failure as a transportation route became clear-so clear that in 1902 railroad baron James J. Hill called for an end to river improvement. Hill's remarks frightened cities and businesses along the river already suffering from the timber industry's decline, and triggered the first sustained river improvement effort by midwesterners. ${ }^{8}$ Following Hill's speech, navigation boosters met in Quincy, Illinois. Acknowledging that they had neglected the river for twenty-five years, they nonetheless protested Hill's remarks. "We regard the Mississippi River of such mighty value in our occupations and to our respective communities," avowed one booster, "that we do not propose to have it slandered, or permit it to be neglected." 9

For the next five years, navigation boosters pushed for a six-foot channel, and on March 2, 1907, Congress authorized

7. U.S. Army, Corps of Engineers, Annual Reports of the Chief of Engineers (Washington, DC, 1892-1909).

8. Philip V. Scarpino, Great River: An Environmental History of the Upper Mississippi, 1890-1950 (Columbia, MO, 1985), 37, says that towns along the river formed the Upper Mississippi River Improvement Association due to the loss of timber-related businesses. They hoped that by reviving the river they could revive their sinking economies.

9. Proceedings of the Upper Mississippi River Improvement Association Convention Held at Quincy, Illinois, November 12-13, 1902 (Quincy, IL, n.d.), 6, 8-9. 


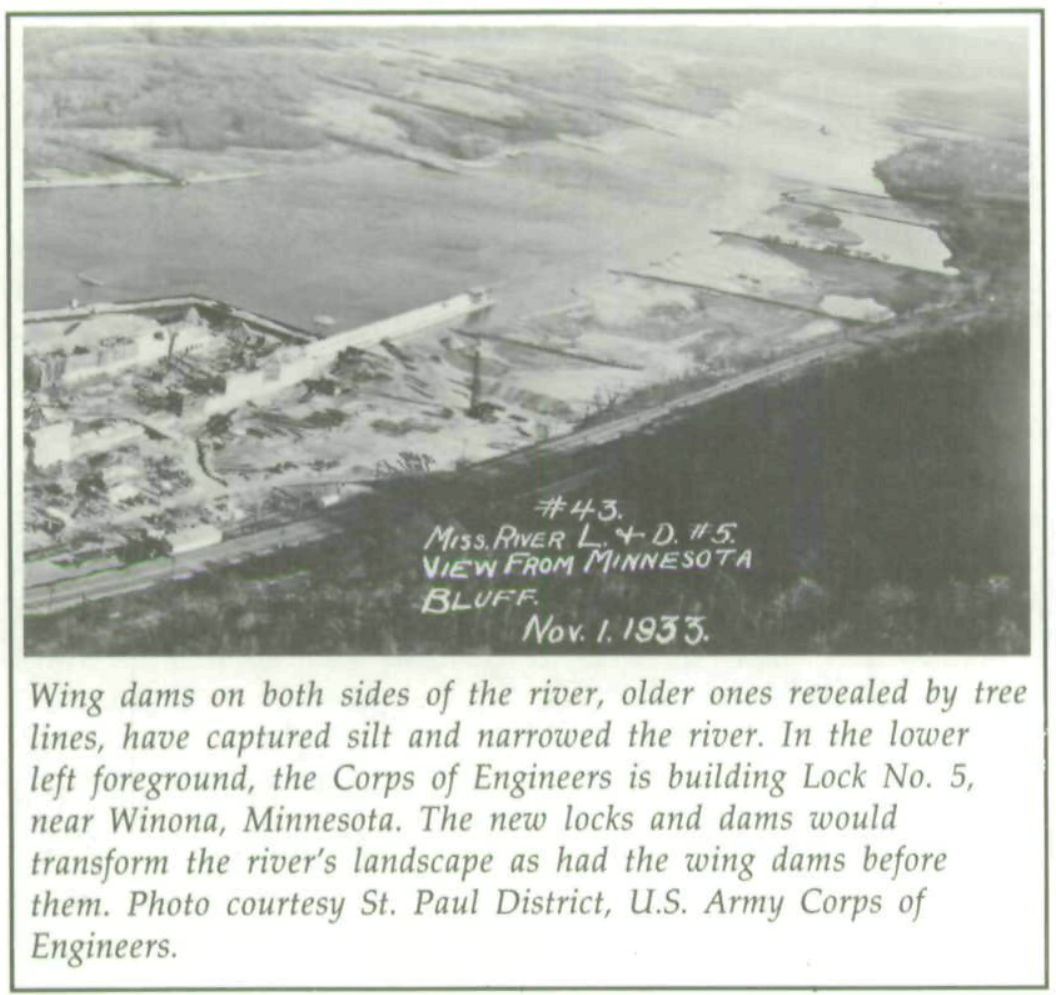

it. The project called for more wing dams and closing dams and more dredging. By 1930, the Corps had built thousands of wing dams in the upper Mississippi River and had closed hundreds of side channels. In many reaches, wing dams lined both banks. Trees and other plants grew from the dams, and great quantities of silt collected between them, transforming the river's landscape and ecosystems.

DESPITE THE DRAMATIC CHANGES caused by the $4 \frac{1}{1} 2$ and 6-foot channel projects, few conservationists opposed them during the late nineteenth and early twentieth centuries. During the early part of that era, those conservationists who wanted to preserve the river's fish and wildife and its natural landscape had not yet organized to voice their concerns. As conservation became a "national fad" during the early twentieth century, its goals were not so different from 
those of navigation boosters who sought to use the river to its fullest extent as a commercial highway. Most early conservationists promoted the most efficient use of the country's resources. To fish and wildlife conservationists, that meant promoting sport and commercial uses, without diminishing the numbers of popular species. On the upper Mississippi, national and regional conservation interests began improving the river for recreation soon after the Corps began improving it for navigation. ${ }^{10}$

Fish management provides a good example of the vision early conservationists held for the river and how their vision shaped it. Fish management began on the upper Mississippi soon after Congress created the Office of the U.S. Commissioner of Fish and Fisheries in 1871 to address the country's decreasing populations of food and game fish. Initially, Congress authorized the commission to study fishery problems, but, in 1872, it expanded the commission's duties to include propagating and planting fish. Although the upper Mississippi fishery was not in danger, the commission and the commercial and sport anglers it served wanted the river to yield more of what they considered popular food and game species. Thus, the commission introduced American shad and Atlantic salmon into the river. In 1872-six years before Congress authorized the $4 \frac{1}{2}$-foot channel project-the commission distributed twenty-two thousand shad below St. Anthony Falls, and from 1874 to 1884 it placed more than 1.3 million shad in the river. Neither the shad nor the salmon survived long, but the commission did successfully introduce carp and stock the river with native fish that it thought desirable. ${ }^{11}$

10. Donald C. Swain, Federal Conservation Policy, 1921-1933 (Berkeley and Los Angeles, 1963), 3. For a general history of the conservation movement, see Hays, Conservation and the Gospel of Efficiency. On the development of a constituency for the river's environmental and aesthetic qualities, see Scarpino, Great River, chap. 4.

11. Frank T. Bell, "Proposals for a Solution of the Fishery Conservation Problem," The Progressive Fish Culturalist (February 1936), 1; Harriet Bell Carlander, History of Fish and Fishing in the Upper Mississippi River (n.p., 1954), 26-28. 
Fish management on the upper Mississippi expanded in 1874, when Iowa, Minnesota, Missouri, and Wisconsin established fish commissions. Iowa's commission, under its first commissioner, B. F. Shaw, initiated the most important program. Shaw initially focused on propagation, but he soon turned to another source. Each spring, when the Mississippi flooded, fish entered the river's backwaters to spawn. As the water receded, the adult fish returned to the river. Fingerlings-numbering in the hundreds of millions-remained and became stranded. As the shallowest pools evaporated, the fish in them died. Many pools that lasted through the summer and fall froze solid in winter. Even where they did not, the fish often became so concentrated that they suffocated. Looking for a cheap source for stocking fish, Shaw recognized the trapped fingerlings as a tremendous resource. During the early 1870 s he experimented with fish rescue, taking fingerlings from the backwaters and placing them in the river. In 1876 he convinced Iowa's legislature to fund rescue work, and sent crews into the field during September and October. Despite the short season, they saved more than one million fish. ${ }^{12}$

Other states and the federal government soon followed Iowa's lead. In the 1880s Missouri and Illinois began rescuing fish, and Wisconsin started in 1895. Recognizing the potential of fish rescue, the U.S. Fish Commission started rescue operations in 1889, which it continued after 1903, when it became the Bureau of Fisheries. The bureau quickly dominated fish rescue operations on the upper river, establishing thirtyfour stations between 1917 and 1923. By the early 1920s, fish rescue had become so important to the bureau's program that its chief ichthyologist declared the bureau dependent on the Mississippi for its fingerling supply. In 1923, he reported, the bureau provided thirty-two states with fish from the river.

12. Carlander, History of Fish, 26-28; C. F. Culler, "Fish Rescue Operations," Transactions of the American Fisheries Society 50 (1920), 247-48; Patrick Brunet, "The Corps of Engineers and Navigation Improvement on the Channel of the Upper Mississippi River to 1939" (M.A. thesis, University of Texas, Austin, 1977), 143-44. 
During the 1920 s the bureau rescued 100 to 176 million fish annually. ${ }^{13}$

Fish rescue, its proponents insisted, was regionally and nationally significant. The "importance of this work as a means of maintaining and increasing the food supply of the country," asserted C. F. Culler, chief of the bureau's La Crosse office, "can hardly be equalled in any other field, when cost, results, and quick returns are considered." The great quantity of fish taken from the upper river on a Sunday, he speculated, affected "the Monday income of every butcher" between Wabasha, Minnesota, and Rock Island, Illinois. Yet fishing's economic value, he suggested, was incidental to the recreation and sport enjoyed by anglers. ${ }^{14}$

Fish rescue may have affected the river's ecosystem in important ways, but balancing various elements of that system was not part of the vocabulary or agenda of the conservation movement in the late nineteenth and early twentieth centuries. During the 1916 season Culler proudly reported that rescuers from the Homer, Minnesota, station had reoved fish from "practically all the dead sloughs and pockets" in a thirty-mile reach above La Crosse. Removing fish from stranded pools, however, denied food to birds and animals that preyed on the fingerlings. Culler, a strong proponent of fish rescue, complained that "predacious birds" were a serious problem, as they often consumed the fingerlings before the rescuers could save them. Rescuers counted 102 fish in the stomach of one blue heron they had killed, and Culler himself said he had counted "as many as 25 blue heron around a pool, feasting on young bass." "This is an example," Culler complained, "of the heron menace."15 Clearly,

13. Carlander, History of Fish, 30-32; Brunet, "Corps of Engineers," 144; Senate, Committee on Commerce, Hearings on S. 1558, A Bill to Establish the Upper Mississippi River Wild Life and Fish Refuge, 68th Cong., 1st sess., 15 February 1924, 9-11.

14. Culler, "Fish Rescue," 250; idem, "Depletion of the Aquatic Resources of the Upper Mississippi River and Suggested Remedial Measures," Transactions of the American Fisheries Society (1930), 279.

15. Earl Simpson, "Conservation and Propagation of Fish in the Upper Mississippi River," Transactions of the American Fisheries Society 47 (1917), 36; Culler, "Depletion," 282. Fish rescue also became important in the Bureau of Fisheries' efforts to restock the river's mussels. During the 1890s 
Culler and other fish rescue advocates did not think in the kind of ecological terms that would characterize the conservation movement following World War II.

\section{DURING THE LATE NINETEENTH AND EARLY TWEN-} TIETH CENTURIES, the U.S. Fish Commission, the Bureau of Fisheries, and the state fish commissions represented commercial and sport anglers. To satisfy those interests, they had focused on replacing fish, and did not consider protecting habitat. By the second decade of the twentieth century, however, pollution, siltation, and overuse threatened to overwhelm the river's fish and wildlife, leading conservationists to initiate two efforts to reserve and develop large parts of the upper Mississippi for native plants and animals and for recreation. First, they tried to establish a national park, and second, they sought to create a national wildlife and fish refuge. ${ }^{16}$ Through these two movements, conservationists more clearly defined their visions for the river and organized more effectively to achieve those visions.

Iowa conservationists led the national park movement. As early as 1909, Iowa state representative George H. Schulte of Clayton County tried to convince his fellow legislators in the Iowa General Assembly of the values of such a park in his county, near McGregor. He asked the state legislators to call upon Congress to make the area around McGregor into a national park. ${ }^{17}$ His call went unanswered. In 1916 a small but zealous group of Iowa conservationists revived the park movement. That group had organized to fight against wildlife reduction and had been working for many years to set aside

and early 1900s, mussel shells became popular for making buttons-so popular that mussel collectors threatened to eliminate some species. To replenish the mussels, the bureau began infecting rescued fish with mussel larvae from popular commercial species. The larvae spent the first several weeks of their lives on the gills of certain fish and then dropped to the river bed. The millions of rescued fish represented a tremendous opportunity to restore the river's mussels. See Scarpino, Great River, chap. 3; and Carlander, History of Fish, 39.

16. Scarpino, Great River, chap 4.

17. Jill York O'Bright, The Perpetual March: An Administrative History of Effigy Mounds National Monument (Omaha, 1989), 47-48. 
scenic areas, especially in northeastern Iowa, as state parks. ${ }^{18}$ Now, arguing that the Midwest did not have a national park and was, therefore, entitled to one, they convinced Senator William S. Kenyon and Representative Gilbert Haugen, both of Iowa, to introduce bills to establish a Mississippi Valley National Park in northeastern Iowa. ${ }^{19}$

Park proponents called for the park to preserve the river's scenic and natural areas. "We are just beginning in our country to realize the fearful ravages we have been permitting for so long, ravages of wood, mountain and fen, ... of the beauty and grace of the hillside and dell," one booster lamented. Proponents stressed scenic qualities, but they also asserted that the park was necessary to save migratory birds and protect native plants, animals, and fish. The park's congressional supporters submitted their bill repeatedly between 1916 and 1924, but Congress rejected it each time. ${ }^{20}$ Nonetheless, the park effort publicized the river's natural and scenic qualities and increased awareness of the river's importance as a fish and wildlife reserve. By demonstrating that a constituency was emerging to challenge navigation's supremacy on the river, the park movement led the way for the refuge movement.

18. Brunet, "The Corps of Engineers," 145, argues that this effort marked the beginning of a formal conservation movement in Iowa. See also Conard, "The Conservation Movement in Iowa," E-96. Rebecca Conard, "Hot Kitchens in Places of Quiet Beauty: Iowa State Parks and the Transformation of Conservation Goals," Annals of Iowa 51 (1992), 441-79, provides the best history of the state parks movement in Iowa.

19. C. H. McNider, "What the Mississippi Valley National Park Would Mean to Iowa," Iowa Conservation 1 (1917), 30; O'Bright, Perpetual March, 48; Brunet, "The Corps of Engineers," 145; George Bennett, "The National Park of the Middle West," Iowa Conservation 2 (1918), 43-47. Bennett, a retired Episcopal minister from McGregor, became one of the park's leading advocates.

20. Bennett, "National Park," 46; Brunet, "The Corps of Engineers," 146. In part, the park movement failed because Congress had traditionally created parks from federal lands; the proposed park would have required purchasing a lot of private land. It also failed because supporters were unable to create national backing for the project; it appeared to be more of a regional boon. See Raymond H. Merritt, The Corps, the Environment, and the Upper Mississippi River Basin (Washington, DC, 1984), 43. 
As the park effort stalled, conservationists initiated a new movement, one that would exceed its predecessor in vision and accomplishment. In 1922 Will Dilg, cofounder of the Izaak Walton League, suggested that Congress create a national fish and wildlife refuge. The refuge would extend over 260 miles through the upper Mississippi River valley, between Wabasha and Rock Island. To convince Congress to act quickly and positively on the bill, refuge proponents argued that the upper Mississippi River valley faced an environmental crisis. If Congress did not create the refuge immediately, the nation would lose one of its greatest fish and wildlife reserves, important commercial food and fur resources, the best recreation area in the central United States, and spectacular scenery. H. C. Oberholser, speaking for the Biological Survey, Department of Agriculture, asserted that "we must, if we are to keep up the supply of our wild life, do something before it is too late; and it is rapidly becoming too late." Dilg and other conservationists claimed that the proposed refuge area represented the river's last stand for fish and wildlife. ${ }^{21}$

The draining of wetlands spurred conservationists, under Dilg's leadership, to push for the refuge. In their testimony before Congress on the refuge bill, and in their many writings, conservationists detailed what the loss of the river's wetlands would mean, not only to the region, but to the country. They insisted that destroying the wetlands would eliminate North America's most important flyway for migratory waterfowl. Dilg touted the proposed refuge as the greatest bass fishery in the country, and asserted that Americans favored bass over all other fish. But, he predicted, bass would become extinct in the upper Mississippi River unless Congress established the refuge soon. Refuge proponents also argued that losing the upper Mississippi's wetlands menaced not only the river's fish and wildlife but the Midwest's economy, which relied on tourism, the river's sport and commercial fisheries, its mussels, and its waterfowl. To some refuge

21. House, Hearings before the Committee on Agriculture on H.R. 4088, "A Bill to Establish the Upper Mississippi River Wild Life and Fish Refuge," 68th Cong., 1st Sess., 11, 12, 13 February 1924, 35, 4. 
proponents, losing the river's fisheries would even affect the country's moral character. Missouri representative Harry B. Hawes, the bill's sponsor, argued, "We are going to make mollycoddles of our kids if they don't know how to use a fishing rod and a gun. We are going to lose the best American traditions if we do not have a place for our boys to play." He believed that the refuge would draw children from around the country. ${ }^{22}$

Drainage projects threatened all the river's fish-not just bass-as well as the fish rescue program. Diking the river's banks and draining its backwaters eliminated the overflow lands and pools from which federal and state agencies rescued fish. Compounding this problem, removing the backwaters would force the river's water down one channel, increasing its velocity. While beneficial to channel constriction, a faster flowing river, conservationists argued, would endanger fish and wildlife. The annual spring flood would sweep spawning fish down the main channel. Frances E. Whitley, chair of the General Federation of Women's Clubs' Conservation Division, argued that a faster flowing river would prevent mussel larvae from attaching to host fish, reducing mussel populations already threatened by pollution, silt, and over-collecting. "A stream flowing down between its banks, without any extensive overflow is a barren stream and necessarily so," Stephen A. Forbes, a fisheries expert from Illinois, reported to Congress. The Saturday Evening Post joined the call for the refuge. "It is time for America to wake up and to call a halt on waste and our haste to develop every resource regardless of conditions," it argued. "These great swamps ... may conceivably be a better national asset in their natural state than under cultivation." 23

Congress quickly passed the refuge bill, and on June 7, 1924, President Calvin Coolidge signed it, creating the Upper Mississippi River Wildlife and Fish Refuge. Where park proponents had failed, Dilg succeeded in making the refuge a national concern, not just a regional boon. Conservationists gained more than the refuge. They established an organiza-

22. Ibid., 4, 15, 41-42, 50, 86-87, 90.

23. Ibid., 24, 48, 63; Saturday Evening Post, 3 May 1924, 132. 
tion that could bring their vision for the river to life, and they now had something to protect and foster. ${ }^{24}$ They had established the foundation of future environmental efforts to protect the river.

JUST AS CONSERVATIONISTS achieved a major victory, navigation on the upper river died. By 1918, no through traffic moved between St. Paul and St. Louis. As the region's need for a multifaceted transportation system had grown, its shipping options had declined, creating a transportation crisis. The crisis had been building for more than fifty years. Its origins lay in the upper Mississippi's failure to be a competitive transportation route after railroads enmeshed the Midwest, but other factors contributed. Railroad car shortages, the Panama Canal's opening, and the Interstate Commerce Commission's decision in the Indiana Rate Case of 1922, combined with channel constriction's failure, erected what midwesterners considered an "economic barrier" around their region.

Although the Corps of Engineers had built thousands of wing dams and had closed many of the river's side channels, they had been unable to create a dependable navigation channel. All too frequently, droughts and floods rendered the river impassable. Rail car shortages, occurring in 1906-7, during World War I, and in 1921, caused acute, short-term shipping crises, and pointed out the Midwest's dependence on railroads. ${ }^{25}$ The Panama Canal's opening in 1914 redefined

24. Scarpino, Great River, 9, 116-17, 135. Despite the apparent conflict between the refuge and channel constriction, the War Department did not oppose the refuge. Rather, the Secretary of War placed an amendment in the bill stipulating that the refuge would not prevent further navigation improvement. See Merritt, The Corps, 45. Scarpino, Great River, 142-50, provides a good analysis of why the refuge movement succeeded as opposed to a movement to protect part of Yosemite from a dam project. The failures of preservationists at Yosemite were similar to those of the advocates of a national park on the upper Mississippi.

25. Herbert Quick, American Inland Waterways, Their Relation to Railway Transportation and to the National Welfare: Their Creation, Restoration, and Maintenance (New York, 1909), 77. The 1920s farm crisis made farm organizations and farm equipment manufacturers some of the strongest supporters of navigation improvements during this decade. 
the Midwest's transportation problems. Although railroad car shortages had been infrequent, the Panama Canal created a problem that threatened to become steadily worse. Economically, the canal moved the East and West coasts closer to each other, relatively isolating the Midwest from both coasts. Now, New York businesses could ship goods to San Francisco through the Panama Canal more cheaply than midwesterners could ship goods to either coast by rail. ${ }^{26}$

The transportation crisis climaxed with the Interstate Commerce Commission's (ICC) decision in the Indiana Rate Case of 1922 and the subsequent decisions that upheld it. On October 22, 1921, the Public Service Commission of Indiana and others challenged the Midwest's railroad rate structure. Railroads operating out of Illinois and cities along the west bank of the Mississippi River in Missouri and Iowa, they argued, unfairly charged lower rates than railroads running out of Indiana. A 1909 decision by the ICC had upheld the lower rates based on the potential and reality of waterway competition. In the Indiana Rate Case, the ICC reversed that decision. Now, it stated, "Water competition on the Mississippi River north of St. Louis is no longer recognized as a controlling force but is little more than potential." In effect, the commission declared the Midwest landlocked. On February 14, 1922, the ICC ordered railroads operating along the river to raise their rates, leading to a 100 per cent or greater rise in some midwestern shipping rates. ${ }^{27}$

26. Roald Tweet, History of Transportation on the Upper Mississippi and Illinois Rivers (Washington, DC, 1983), 77; Herbert Hoover, "The Improvement of Our Mid-West Waterways," Annals of the American Academy 135 (January 1928), 15-24; idem, "Address at Louisville, Kentucky, October 23, 1929, in celebration of the Completion of the Nine-foot Channel of the Ohio River," in William Starr Myers, ed., The State Papers and Other Public Writings of Herbert Hoover, 2 vols. (New York, 1934), 1:116-22; Franklin Snow, "Waterways as Highways," North American Review 227 (May 1929), 592.

27. Public Service Commission of Indiana Et Al. v. Atchison, Topeka \& Santa Fe Railway Company, Interstate Commerce Commission Reports, Decisions of the Interstate Commerce Commission of the United States, vol. 66, no. 11388 (January to March 1922), 512-22; ibid., vol. 88, no. 11388 (February to April 1924), 709-24; ibid., vol. 88, no. 13671, 728-42. 
That decision, along with the effects of the railroad car shortages and the opening of the Panama Canal, convinced some businesses to leave the region and others to pass it by. Consequently, midwestern business and navigation boosters initiated another movement to revive navigation on the river, a movement that exceeded all previous movements in scope and strength. Between 1925 and 1930, they fought to restore commerce and to convince Congress to authorize a new project for the river, one that would allow the river to truly compete with railroads.

During the first weeks of 1925, the Minneapolis Real Estate Board began organizing the movement to restore commerce. To generate enthusiasm for their project, the board invited prominent river boosters to Minneapolis to speak to its business leaders. ${ }^{28}$ Halleck W. Seaman, one of those boosters, had been promoting transportation for most of his life. A lawyer and civil engineer from Clinton, Iowa, Seaman was president of six railroad companies and managed another by 1911. Transcending his association with railroads, Seaman had become a booster of Iowa and the region. ${ }^{29}$ In late May 1925 he addressed a fifty-member shippers committee and the Minneapolis Real Estate Board. The "ultimate growth and development of Minneapolis," he warned, "depended primarily upon the extent to which river facilities were developed." To Seaman, Iowa's future also depended upon reviving the river. He recognized the need to secure popular support for waterway improvement. "By persistent effort," he encouraged the board, "we will put the whole Mississippi Valley into a good big blaze of enthusiasm for the return of river navigation on a large scale." ${ }^{\prime 30}$

28. "Report of the Industrial Committee," The Realtor 10 (29 December 1925), 2; "Minneapolis An Inland Port," The Realtor 10 (4 May 1926), 2.

29. "Halleck Seaman, Man of Vision," Clinton Herald, Centennial Edition, 18 June 1955; William Patrick O'Brien, Mary Yeater Rathbun, and Patrick O'Bannon, Gateways to Commerce: The U.S. Army Corps of Engineers' 9-Foot Channel Project on the Upper Mississippi River, ed. Christine Whitacre, 23, 25n.

30. "Echoes from Last Thursday's Luncheon," The Realtor 9 (2 June 1925), 2. In a Waterways Journal article titled "What's the Matter with Iowa?" (31 July 1926), 5-6, Seaman blamed Chicago's "trade ambitions" and railroads for arresting Iowa's development. "With the Mississippi restored to its 
In fact, the movement did eventually draw support from the largest and smallest businesses in the valley, from most of its cities, from the Midwest's principal farm organizations, and from the major political parties. The Mississippi Valley Association, which promoted river improvements throughout the entire Mississippi River basin, comprised representatives from all of the states in the Mississippi valley. Yet when the association held its first annual meeting in St. Louis on November 23 and 24, 1925, cities from the upper river sent the largest delegation. Minnesota Governor Theodore Christianson, Minneapolis Mayor George E. Leach, and St. Paul Mayor Arthur Nelson led the delegation, which included representatives from Cedar Rapids, Clinton, Davenport, and Dubuque, Iowa; Moline, Rock Island, and Quincy, Illinois; Minneapolis, St. Paul, Stillwater, and Winona, Minnesota; and LaCrosse, Wisconsin. ${ }^{31}$ The number and prominence of businessmen and politicians who traveled to St. Louis demonstrated how important reviving navigation was to the upper Mississippi valley.

As the first task in their effort to restore commerce to the river, navigation boosters spent most of 1925 negotiating with the Coolidge administration to have the Inland Waterways Corporation (IWC), a government shipping agency left over from World War I, operate on the upper Mississippi River. On January 20, 1926, boosters signed an agreement with the IWC. The agreement required a new and greater commitment from river cities and shippers. Rather than leaving terminal and fleet development to private interests, the cities and shippers would have to help finance these enterprises. As part of the agreement with the IWC, boosters had agreed to raise at least six hundred thousand dollars to build a new fleet, which they would then lease to the IWC. In addition, boost-

rightful function as a modernized carrier of commerce," Seaman argued, Iowa's river towns would begin booming. "Iowa can then boast of the big towns on the river," he declared, but now, he lamented, "she apologizes for them as the runts in the litter."

31. "Strong for the River," The Realtor 10 (1 December 1925), 2; H. G. Benton, "Minneapolis Continues River Activity," Waterways Journal 38 (12 December 1925), 10. In 1925 boosters also created the Upper Mississippi River Barge Line Company to push for river improvements. 
ers had to convince cities and towns along the river to spend tens of thousands of dollars to build modern terminals. Within three months, the boosters had successfully raised the funding needed to build the fleet and had begun working with river towns to improve or build terminals. On August 25,1927 , waterway development proponents celebrated a "Minneapolis-to-the-Gulf Day" upon the arrival of the first IWC towboat and barges in Minneapolis. ${ }^{32}$ For the moment, they had restored river commerce.

A serious problem remained, however. The six-foot channel was too shallow and unpredictable to carry commodities reliably and in the quantities needed to meaningfully reduce transportation costs and ensure profitable barge line service. ${ }^{33}$ Supporters recognized that only by damming the river could they obtain the economies of scale needed to restore river commerce permanently, encourage private investment, and guarantee a deep and reliable channel. ${ }^{34}$ Once they had established barge line service, navigation boosters actively pushed for a deeper channel, and on January 21, 1927, Congress authorized the "Preliminary Examination of Mississippi River between Missouri River and Minne-

32. "Minneapolis to-the-Gulf Day," brochure, 25 August 1927, Upper Mississippi Barge Line Company (UMBLC) Records, 1919-1937, Minnesota Historical Society, St. Paul, Minnesota; "First Voyage," Minneapolis Morning Tribune, 26 August 1927. Scarpino, Great River, 166-77, suggests that the Corps maneuvered river cities into building terminals. Once they had put thousands of dollars into the terminals, he argues, they had little choice but to push for the nine-foot channel project. The records of the UMBLC, however, clearly demonstrate that the Corps did not lead or direct the effort to revive commerce on the river or to establish the ninefoot channel.

33. H. G. Benton, "Minneapolis Continues River Activity," Waterways Journal 38 (12 December 1925), 10. "A Nine Foot Channel for Minneapolis," The Realtor 10 (1 December 1925), 2, said that the push for a deep channel came in response to the City of Chicago's effort to deepen the Illinois River to nine feet.

34. To this end, they needed a nine-foot channel and equitable joint relations with connecting carriers. J. L. Record to A. C. Wiprud, 19 February 1928, UMBLC Records; "Resolution adopted by the River Cities Convention of the Upper Mississippi Valley at Minneapolis, February 20, 1928," UMBLC Records; untitled and unsigned, [Pre-May, 1928], UMBLC Records, says that they needed guaranteed operation of the barge line until successful private operation was established. 
apolis with a view to securing a channel depth of 9 feet with suitable widths." ${ }^{15}$ Deep channel advocates felt confident that the survey would demonstrate the economic need for such a project.

To the boosters' surprise, the Corps questioned the economic and environmental effects of the nine-foot channel project. The Corps' Major Charles L. Hall, the Rock Island District Engineer who directed the survey, shocked nine-foot channel advocates on August 25, 1928, by submitting an unfavorable report to the Chief of Engineers. Hall argued that the thirty-year decline in traffic on the upper river demonstrated that it was not worth improving. Navigation boosters responded quickly. Five days after Hall submitted his report, one booster exclaimed that Hall's report had "resulted in a volume of protest which is without parallel in this movement." By October 6, the Corps ordered Major Hall to reassess his report. Hall held his position, and on February 27, 1929, delivered a second negative report. Again, navigation proponents objected, organizing a publicity campaign against Hall and forming a team of experts to argue successfully for yet another survey. This time the Corps assigned the survey to a special commission, making Hall one of the commissioners. ${ }^{36}$

35. Congressional Record, 75th Cong., 1st sess., Appendix, 2155; Annual Report, 1927, 1084.

36. Major Robert C. Williams, St. Paul District Engineer, to C. C. Webber, 16 August 1928; Major C. L. Hall to Upper Mississippi Division, Inland Waterways Corporation, 25 August 1928; A. C. Wiprud to Cornelius Lynde, 31 August 1928 (and extensive correspondence in box 2, folder for August 1928); A. R. Rodgers to Major General Edgar Jadwin, 6 October 1928; Major C. L. Hall to Minneapolis Civic and Commerce Association, 10 October 1928; A. C. Wiprud to Theodore Brent, 27 February 1929; A. G. Godward, executive engineer, to Hon. Walter H. Newton, 12 March 1929; John H. Carruth, Major, Corps of Engineers, Chief, Personnel Section, Special Orders No. 31, 29 May 1930, all in UMBLC Records. Raymond Merritt, "The Development of the Lock and Dam System on the Upper Mississippi River," National Waterways Roundtable Papers, Proceedings: History, Regional Development, Technology, A Look Ahead (Washington, DC, [1980?]), 97-98, says that the Chief of Engineers asked Hall to reassess his survey because it was an election year. As evidence, he says that as election day neared, the administration ordered Hall to reassess his report, appeasing the Mississippi River valley. The day after the election, Merritt points out, the chief called the project economically unjustified. 
Nine-foot channel boosters feared that the Corps would not finish the survey in time for Congress to include the project in the 1930 Rivers and Harbors bill. Time was becoming critical. Boosters feared that if they did not get their project in this bill, they might never obtain a deep channel. Numerous eastern projects encumbered the bill, and midwesterners worried that once the easterners had their projects they would not support a bill with a nine-foot channel for the upper Mississippi. Their fears intensified when the House convened in December 1929 and accepted the Rivers and Harbors bill without the upper Mississippi River nine-foot channel project. Not until February 15, 1930, did the Secretary of War submit the survey report to Congress, and then only as an interim report. ${ }^{37}$

Although the special commission found the project worthy, neither the commission nor the Corps' Board of Engineers for Rivers and Harbors favored immediate or full authorization. In submitting the report to the Chief of Engineers, the board concluded, "This is a very important project, justifying most careful and detailed study. From the information available the Board of Engineers for Rivers and Harbors is unable to determine upon a satisfactory plan, either for betterment of the existing project or for the provision of a 9-foot depth." The board recommended waiting for the final survey, due in December 1931, and continuing work on the six-foot channel. ${ }^{38}$

Navigation boosters fared no better with Congress or President Herbert Hoover. Hoover, who had supported waterway development as Secretary of Commerce under presidents Harding and Coolidge, "astonished" boosters by supporting the Corps' position, and the House Rivers and Harbors committee refused to add the project to the Rivers and Harbors bill. A depression, Hoover insisted, was not the

37. George C. Lambert to Honorable James W. Good, Secretary of War, 31 August 1929, UMBLC Records; George C. Lambert, Mississippi and St. Croix River Improvement Commission, to Honorable James W. Good, 31 August 1929, UMBLC Records; House, "Mississippi River Between the Mouth of the Missouri River and Minneapolis, Minn." (Interim Report), 71st Cong., 2d sess., 1930, H. Doc. 290.

38. "Mississippi River" (Interim Report), 1-11. 
time to fund such a massive project. ${ }^{39}$ Responding to pressure from the nine-foot channel advocates, Walter $\mathrm{H}$. Newton, a secretary to the president, wrote to Charles C. Webber, one of the leading boosters, defending Hoover's choice for the job of Chief of Engineers and contending that Hoover had placed "the best river man" in charge of work on the upper Mississippi River. Both engineers opposed authorizing the project without the detailed survey. If boosters could be patient, they would eventually get their project. As for the House Rivers and Harbors Committee, Newton reported that it had decided to listen to its experts-the Corps of Engineers. ${ }^{40}$

Webber's response to Newton revealed much about the upper Mississippi valley's sentiment. Webber said that while he appreciated the value of a detailed survey, the administration could not blame the boosters for being impatient. Congress, he complained, should have included the nine-foot channel project as a part of the act authorizing the Panama Canal, and the Midwest had "patiently suffered ever since." "Public opinion in the valley is united for immediate authorization in spite of attempts to divide it," he reported. "It is too late now to stem the tide and solidarity of public opinion on this subject." Boosters in the valley doubted that Congress would authorize their project in another Rivers and Harbors bill. They still hoped that the president would save their project, but they were unwilling to quit or compromise if he did not. "There is a time," Webber concluded, "when patience ceases to be a virtue." 41

39. Clarence Wiprud to C. C. Webber, 14 February 1930, UMBLC Records; Clarence Wiprud, The Search for Wider Horizons (Richmond, VA, 1970), 43. The Hoover administration did not oppose the nine-foot channel project. Rather, it thought that the timing for full authorization was bad. The Great Depression had begun less than five months earlier, and Hoover believed that the financial condition of the country was not good enough.

40. Walter H. Newton, Secretary to the President, to Charles C. Webber, Deere \& Webber Company, 17 April 1930, UMBLC Records.

41. C. C. Webber, President, Upper Mississippi Barge Line Company, to Walter H. Newton, Secretary to the President, 19 April 1930, UMBLC Records. Evidencing his lack of patience, A. C. Wiprud, Secretary and Counsel, Upper Mississippi Barge Line Company, wrote to H. M. Hill, Janney, Semple, Hill \& Co., 10 March 1930, UMBLC Records, "This is election year and if the Administration is to frown upon this proposed devel- 
Supporters of the deep channel had lost their patience as chances for their project dimmed. The Rivers and Harbors Committee sent the bill to the full House without recommending authorization of the nine-foot channel project, and on April 25 the House passed the bill. The Corps, the House, and the president had rejected the call for a nine-foot channel on the upper Mississippi River. The last chance was for the Senate Commerce Committee to add the project to the Rivers and Harbors bill before sending it to the full Senate.

In contrast to previous efforts, the Senate battle went smoothly. Minnesota Senator Henrik Shipstead led the fight. By May 13, 1930, he had convinced twenty-one of his colleagues to sign a petition for the project, and by May 21 the Commerce Committee had voted fifteen to four to include it in the bill. ${ }^{42}$ Only a veto of the Rivers and Harbors Bill could kill the project now. On June 16 the full Senate passed the bill, and by June 24 the House accepted the Senate's version. On July 3, 1930, President Hoover signed it. ${ }^{43}$

For more than fifty years, the Corps' channel projects had constricted the river, but had failed to bring commerce back. With the nine-foot channel project, the Corps initiated a completely new approach to navigation improvement. The locks and dams would widen and deepen the river, slowing its pace. In doing so, the Corps would create a more reliable navigation channel and enable shippers to match or exceed the economies of scale enjoyed by railroads. The wider, deeper, and slower-moving channel would affect the river's ecosystems in ways far different from channel constriction.

opment, in the light of the President's Louisville address last October, there will be very little for the Republican congressmen to campaign on during the forthcoming primaries and election."

42. Wiprud, Horizons, 44 , says that he had twice suggested that Senator Shipstead submit a petition to senators from the river valley, but Shipstead had declined.

43. A. C. Wiprud to A. R. Rodgers, 13 May 1930; A. C. Wiprud to Colonel George C. Lambert, 21 May 1930; A. C. Wiprud to C. C. Webber, 16 June 1930; Godfrey Goodwin, M.C., to A. C. Wiprud, 24 June 1930, all in UMBLC Records. 
CONSERVATIONISTS did not use their new-found strength to fight the nine-foot channel project's authorization. Why they did not is not clear. As the Corps, Hoover, and key congressmen opposed authorizing it, conservationists may have assumed that it would not be included in the 1930 Rivers and Harbors Act. When it was, they began challenging it. Conservationists living along the refuge, especially those in northeastern Iowa, protested against the project. Congressman Frederick Biermann, whose district included the river around McGregor and Guttenberg, Iowa, became one of the project's most vocal opponents. Three times during the 1930s he introduced legislation to kill the nine-foot channel project. He stressed both environmental and economic reasons. The pools created by the dams, he argued, would submerge much of the wildlife and fish refuge and destroy the growing tourist trade that the refuge had been attracting. Biermann also believed that the project, if successful, would steal traffic from railroads paralleling the river. The railroads paid significant taxes in his district and others along the river, so their demise, he contended, would hurt these districts. ${ }^{4}$

A. C. Willford, another U.S. Representative from Iowa, also opposed the navigation project. A national director and the Iowa state director of the Izaak Walton League, Willford stressed the league's role in establishing the Upper Mississippi Wild Life and Fish Refuge. The refuge, he asserted, was "the only outdoor park" in the central United States. Furthermore, he argued, the dams would inundate the Winneshiek Bottoms, a large wetland that Dilg and the league had sought to preserve when they called for the refuge. Willford agreed with Biermann that silt would fill in the river, making the dams useless, and pollution would turn the reservoirs behind the dams into stagnant cesspools. An invaluable natural resource, he concluded, would be wasted by a project that had no chance of succeeding. The nine-foot channel project,

44. House, Committee on Rivers and Harbors, "Hearings before the Committee on Rivers and Harbors, Improvement of the Upper Mississippi River," 73d Cong., 1st sess., 2, 3, 4, and 5 May 1933, 4-5, 46-48. 
Willford charged, was "merely a dream.... an engineer's dream." 45

Undermining Biermann and Willford, the Bureau of Fisheries concluded that the nine-foot channel would not harm the river's fisheries. The bureau had studied the river during the summer and early fall of 1930. Their research showed that where drainage and levee construction had not eliminated backwater areas, the river's game fisheries remained good. As long as the government preserved side channel sloughs, swamps, and marshes, fish would be abundant. The bureau acknowledged that the river's fisheries would continue declining if pollution and siltation were not reduced, but concluded that the river faced these problems with or without the dams. ${ }^{46}$ The bureau held some reservations about the nine-foot channel project, however. Capitalizing on the concerns raised by Biermann and others, it worked with the Corps to reduce the project's adverse effects on fish and wildlife.

Throughout its final report on the nine-foot channel project, which was submitted to Congress on December 9, 1931, the Corps discussed the many factors that influenced the project's design, including fish and wildlife. In calling for twenty-three locks and dams, the Corps took special note of the refuge. As the Bureau of Fisheries had hoped, the Corps selected low-head dams, which would not raise flood levels and leave towns, roads, railroads, levees, farm lands, and the refuge submerged. On the other hand, the bureau had also hoped for fixed dams to prevent the Corps from lowering the pools too much, but the Corps chose dams with movable gates, arguing that fixed dams would cause too much damage

45. Ibid., 7-8, 10.

46. House, "Survey of the Mississippi River between Missouri River and Minneapolis," 72d Cong., 1st sess., H. Doc. 137, 1932, 67-68. The bureau confirmed this position in its 1932 annual report, stating, "It is evident that while in itself the construction of dams on the Mississippi River or its tributaries will not adversely affect aquatic organisms but may indeed increase fish production, it will result in increasingly bad conditions until soil erosion is reduced and excessive sewerage pollution is eliminated." See U.S. Department of Commerce, Bureau of Fisheries, Report of the Commissioner of Fisheries for the Fiscal Year 1932 (Washington, DC, 1933), 136. 
to backwater areas during floods. Low-head dams with movable gates, the Corps insisted, would be better for the river's fish and wildlife because the Corps would be able to maintain a higher water level throughout the winter. In addition, strong currents through the gate openings would attract fish, which could then pass through these openings and move upstream-more easily, the Corps believed, than through a fishway. If this proved wrong, the Corps agreed to add fishways. ${ }^{47}$

The Corps selected dam sites based on a variety of criteria, including the effects on fish and wildlife. Potential flowage damages and the river's profile determined the general location, and detailed site surveys identified the final locations and pool elevations. Acceptable sites had straight approaches, adequate foundation conditions, and reasonable access. ${ }^{48}$ Overall, the Corps tried to accommodate fish and wildlife concerns, but navigation requirements clearly ranked first.

The Great Depression threatened to postpone construction of the nine-foot channel project. President Hoover had withdrawn his support. His successor, Franklin Roosevelt, however, recognized the project's importance to the Midwest and saw it as an opportunity to put the unemployed to work. In 1933 Roosevelt signed the National Industrial Recovery Act, providing fifty-one million dollars for the project through the Public Works Administration. In 1935 Congress provided the remainder of the funding through a regular Rivers and Harbors Act.

THE NINE-FOOT CHANNEL PROJECT forced the Bureau of Fisheries to reevaluate its fish management strategy. The new reservoirs would flood the backwater pools from which the bureau had been rescuing fish for more than three decades, eliminating the bureau's primary source of fingerlings.

47. H. Doc. 137, 20-22. The Corps insisted that maintaining a high level throughout the winter would not be good below Muscatine, lowa, where levees were more extensive.

48. Ibid., 20. 
To compensate, the bureau would have to begin propagating hundreds of thousands of fish in controlled ponds.

Even before Congress authorized the nine-foot channel, the bureau had begun experimenting with fish propagation. By the late 1920s, habitat loss had forced the bureau to consider artificial propagation. Pollution, siltation, and drainage had destroyed so much habitat by 1926 that, according to Culler, fishing would soon be "only a memory." The consequences, he warned, would not be limited to the upper Mississippi.

Folks who are now receiving fish from either the Conservation Commissions of the several states or the Federal Bureau of Fisheries will have to look elsewhere for fish with which to stock their lakes and streams, and where else can they be had? There is no other place in the United States where fish for stocking purposes can be had in such numbers, and the few fish they may receive, if this supply is not kept up, will necessarily have to be hatched and reared in control ponds. ${ }^{49}$

Overuse, pollution, and siltation were destroying the upper river's fishery, and the bureau could no longer meet demand from anglers outside the valley by fish rescue alone. Although the bureau had experimented with artificial propagation on the upper Mississippi River before, it had not tried to propagate fish on a large scale. As demand grew, the bureau could not send more rescued fish away. Anglers on the upper river had already protested that the bureau shipped too many fingerlings out, and the bureau had to consider the fishery of its new refuge. If the bureau hoped to meet the increasing demand, it would have to supplement rescue work with artificial propagation. ${ }^{50}$

49. C. F. Culler, "Reclamation of Food Fishes and Mussel Propagation," Transactions of the American Fisheries Society (1926), 175.

50. In Bureau of Fisheries, Report for 1936, 355, the bureau said that fulfilling all the requests that it got for fingerlings would constitute too great a drain on the resources of the refuge. Even though it considered the number of fish sent away from the river negligible, the bureau was sensitive to criticism on this issue. In Bureau of Fisheries, Report for 1928, 351, the bureau reported, "Mindful of the fact that such diversions can not be continued indefinitely, the bureau is taking steps to propagate warm-water 
In 1928 , then, the bureau began studying sloughs in the refuge for their potential as controlled rearing ponds. They hoped that by reshaping the sloughs with the proper flora and fauna they could successfully propagate bass. In the spring of 1930 the bureau planted bass fry in the sloughs that it had been studying. An unusually late June rise, however, flooded five of eight ponds, allowing the fish in them to escape. As the surviving sloughs produced a large number of fingerlings, the bureau remained hopeful for the project. The following year, the bureau again stocked the sloughs with bass. Again, high water flooded them. This time the bureau decided that rearing bass in the sloughs would not be practicable. ${ }^{51}$

Despite this failure, the bureau could not end its fish propagation efforts. Progress on the nine-foot channel was making fish rescue impossible. By 1935, reservoirs created by newly completed dams had eliminated several of the bureau's semicontrolled ponds and had flooded areas previously used for fish rescue. In 1936 the bureau predicted that within a year or two fish rescue would be "a thing of the past." 52

Working together, the bureau and the Corps tried to minimize the effect of the dams on fish and to develop a propagation program. In part, the Corps cooperated because it was required to. The 1934 Federal Coordination Act directed all federal agencies whose activities affected fish and wildlife to coordinate with the Bureau of Biological Survey and the Bureau of Fisheries. The Corps, however, had begun cooperating with the Bureau of Fisheries even before the 1934 act, largely due to pressure from conservationists. Whatever the motivation, in 1935 the bureau reported that "the United States Army Engineers have given sympathetic consideration to the Bureau's recommendations, with regard to developments in the upper Mississippi River area. This has been based upon a hope that the dams comprising part of the

fishes on land under Federal jurisdiction in the Upper Mississippi Wild Life Refuge."

51. Bureau of Fisheries, Report for 1928, 204; ibid., 1931, 606, 607; ibid., $1932,562$.

52. Ibid., 1935, 424; ibid., 1936, 355. 
9-foot channel development might be modified so as to provide extensive propagating ponds for the production of fish native to that area." 53

Budget cuts due to the depression restricted the bureau's program. Although it had been able by 1936 to establish three ponds for rearing bass within the refuge, funding cuts had forced the bureau to close some of its fish culture stations and to limit its rescue work. Fortunately for the bureau, Congress appropriated funds under New Deal relief programs to build additional ponds totaling more than four hundred acres. By 1937, the bureau could assert that "the provision of artificial cultural ponds in the areas adjacent to the pools created by the new dams is an expedient of proved success." Already the bureau had produced sizable hatches of bass and other species in newly constructed ponds. By the end of June, the bureau estimated that it would have stocked its ponds with some four hundred thousand bass fry. The bureau reaffirmed the success of its new ponds in 1938, announcing that during the previous year two newly constructed ponds at Genoa, Wisconsin, had produced more than 864,000 fingerling black bass, at least one hundred thousand more than the bureau had rescued at eight upper river stations in 1928. On July 1, 1938, allocations of $\$ 808,500$ from the Public Works Administration and $\$ 500,050$ from the Works Progress Administration allowed the bureau to expand its hatchery program. ${ }^{54}$

Although the nine-foot channel project forced the bureau to shift from fish rescue to artificial propagation, it did not change its fish management philosophy. Commercial and sport species remained its only concerns. The bureau had already determined that pollution, siltation, and overuse threatened fish habitat and fish most, and it evaluated the nine-foot channel project in that light. It had already decided to propagate fish as the best way to meet the demand for fingerlings, but it did not have the resources or sites to build adequately controlled ponds. The nine-foot channel project

53. Ibid., 1934, 80; ibid., 1935, 91.

54. Ibid., 1934, 96, 98; ibid., 1935, 424; ibid., 1936, 376; ibid., 1937, 93; ibid., 1938, 108; ibid., 1928, 351-52; ibid., 1939, 140. 
provided both. Thus, the bureau determined that as long as the navigation project preserved important breeding and spawning areas, it would not ruin the river's fisheries.

NOWHERE on the upper Mississippi River is the shift to propagation, as forced by the nine-foot channel project, better illustrated than at Guttenberg, Iowa. Nowhere is the compromise between the navigation and conservation movements more clearly represented. Lying side by side, Lock and Dam No. 10 and the Guttenberg fish ponds create a landscape that begs explanation. Any explanation inexorably draws us into local, regional, and national issues and developments.

Conservationists in northeastern Iowa had remained active despite their disappointments over the nine-foot channel project, successfully lobbying for some of the New Deal funds to build a hatchery at Guttenberg. The hatchery and associated rearing ponds represented a strong local, state, and federal partnership. The citizens of Guttenberg initiated the call for the project, and Congressman Biermann convinced Congress to include it in a June 1938 relief appropriations bill. On August 4, 1938, the Guttenberg newspaper reported that Culler had first seen "the efficacy of the location here several years ago. Ever since that time, he has worked tirelessly to get the necessary money." The paper added that Frank T. Bell, the bureau's commissioner, had "aided him at every turn." Bell's work, it emphasized, "probably was the deciding factor in getting allocations from WPA and PWA for the hatchery." On December 5, 1938, Guttenberg donated seven-tenths of an acre of land to the federal government for the project, and removed its old town hall to make room for the hatchery and aquarium. In 1940 the Corps granted an additional 1.84 acres for the hatchery buildings and grounds. When completed, the new facility would include a hatchery and aquarium, a supervisor's house, and five fish ponds. ${ }^{55}$

Workers built the hatchery and aquarium between 1938 and 1939, and constructed five rearing ponds on Twelve Mile Island between 1939 and 1941. The ponds are generally rec-

55. Rebecca Conard, "Guttenberg National Fish Hatchery Rearing Ponds," State Historical Society of Iowa (1991), 5, 4. 
tangular, resting side by side in a "window pane pattern," and cover about forty acres. As with the locks and dams, New Deal programs contributed greatly to the project. The federal government provided thirty thousand dollars from the PWA and forty thousand dollars from the WPA. The bureau reported that some state WPA projects provided additional funding. The National Youth Authority provided workers to assist in surveying the ponds and in maintaining them for several years. The Guttenberg hatchery, the bureau reported, was "an outstanding example" of cooperation between federal and state programs. ${ }^{56}$

Attendance at the groundbreaking ceremony demonstrates how important the project was to all the parties involved. Representing Iowa were its governor, Nelson G. Kraschel, and one of its senators, Clyde L. Herring, who arrived aboard a Bureau of Fisheries boat. Congressman Biermann also attended, as did Iowa's WPA Director Frank Hopkins and Louise Addison Parker of the Iowa State Conservation Commission. Culler represented the Bureau of Fisheries, and Colonel E. E. Gesler, the Rock Island District Engineer, attended for the Corps. The State Relief Administrator N. S. Genung also participated in the ceremonies. ${ }^{57}$

By the time the bureau broke ground for its new facility, the Corps of Engineers had completed Lock and Dam No. 10. Like all the nine-foot channel locks and dams, Lock and Dam No. 10 featured three distinct elements: the lock, the dam, and the onshore buildings. Contractors had begun constructing the lock on February 23, 1934, and completed it on May 29,1935 . Other contractors began building the dam February 11, 1935, and finished it on December 15, 1936. The dam crossed the main channel next to Guttenberg, Twelve-Mile

56. Ibid., 4, 6; Bureau of Fisheries, Report for 1939, 141.

57. Ibid., 1, 2, 4, 5. During the 1960s, the U.S. Fish and Wildlife Service constructed three new ponds, but in 1971 it closed the hatchery and transferred the ponds to the Mississippi River National Wildlife and Fish Refuge. Two years later the refuge abandoned the ponds. Now the Iowa Department of Natural Resources manages the hatchery building and supervisor's house. See ibid., 1, 2, 6. 
MAP

GutTENBERG NATIONAL Fish HATCheRY

AND LOCK AND DAM NO. 10

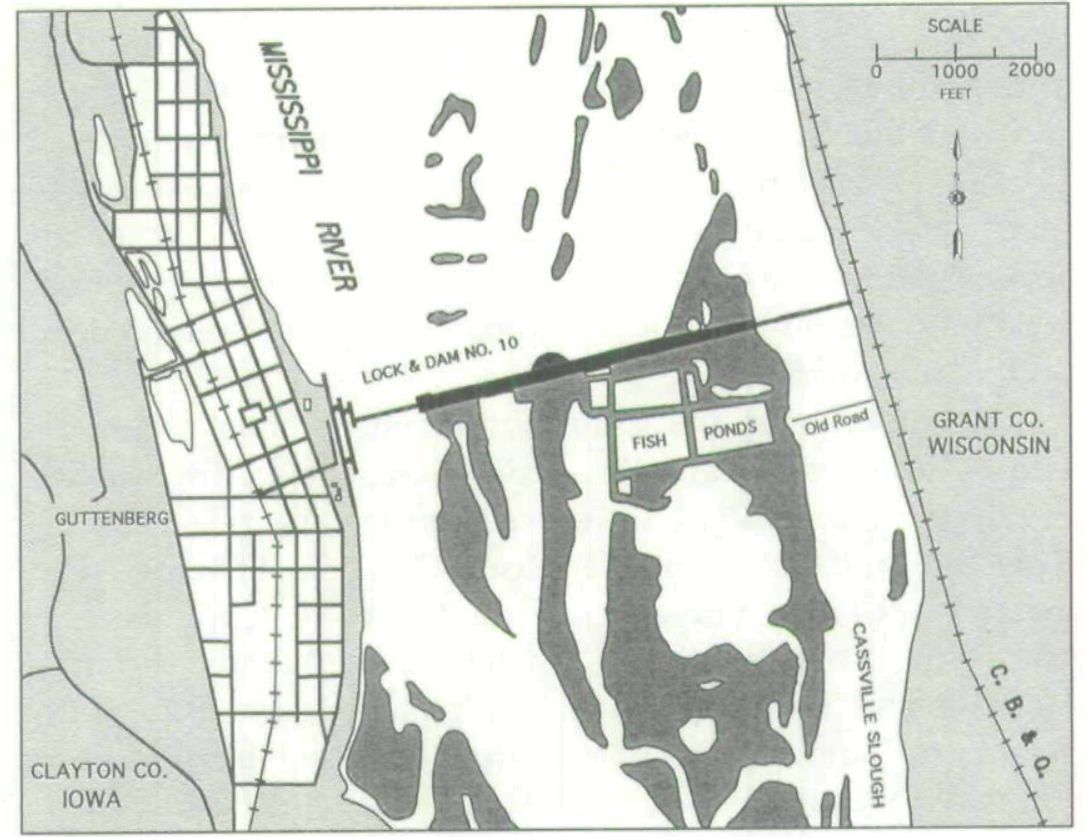

Island, and the old channel, known as Cassville Slough, on the river's Wisconsin side. ${ }^{58}$

When completed, Lock and Dam No. 10 bisected the river, changing its landscape and ecology. Above the dam, the new reservoir flooded many of the low-lying islands and created a vast lake. The river now looked like it might have during high water before the Corps of Engineers built the dam, only it remained permanently high. Below the dam, where the tailwater of the dam downstream reached its lowest point, the river retained many of its islands and braided channels.

58. Construction on the dwellings - the lockmaster and assistant lockmaster houses-began on September 9, 1937, and the Corps accepted the buildings as complete on April 30, 1938. The lockmaster's house is the last of these houses still standing at a lock and dam on the upper Mississippi River. All the other houses have been sold and moved. Between 1930 and 1940, the Corps completed all 23 locks and dams authorized by the 1930 Rivers and Harbors Act. 
There the river looked like it had during much of the year before the Corps built the nine-foot channel. Even at its lowest point, the reservoir covered the wing dams and closing dams, and one gets a sense of what the river looked like before the completion of the $4 \frac{1 / 2}{2}$-foot and 6 -foot channel projects. Together the lock and dam and the fish ponds transformed the river's landscape to meet two different visions of what the river should be.

Conservation and navigation interests are still defining their visions for the upper Mississippi River, and they are still compromising. In an agreement made possible by the Environmental Management Program (EMP), the Corps is modifying the Guttenberg fish ponds in cooperation with the Iowa Department of Natural Resources and the U.S. Fish and Wildlife Service to serve migratory waterfowl. Established in 1986, Congress created the EMP to compensate for the potential ecological effects of adding a second lock at Locks and Dam No. 26, at Alton, Illinois, and the increased traffic it would bring. Under the EMP, federal and state agencies are cooperating in fifty-two habitat restoration and enhancement projects. The origins of this compromise lay in the forces that created the Mississippi's landscape at Guttenberg, Iowa. 
Copyright of Annals of Iowa is the property of State of Iowa, by \& through the State Historical Society of Iowa and its content may not be copied or emailed to multiple sites or posted to a listserv without the copyright holder's express written permission. However, users may print, download, or email articles for individual use. 